\title{
A State Cinematographic Practice in Wartime
}

\author{
The Belgian Army Film Unit 1916-1922
}

Nowadays, the Great War is considered a "matrix of modern media", ${ }^{\text {I }}$ especially in photography and cinema, which underwent an unprecedented development. Mass media widely disseminated iconographic representations of the war. In this profusion of images, the behaviour of state authorities changed, while they had previously looked down on these two types of media. The alleged power of images led belligerents to take control of war pictures which circulated in newspapers or in newsreels. Both the reputation of the Belgian Army, and, behind it, that of the Nation, were at stake. After the outbreak of the war, newsreels were strictly controlled (headquarters obsessively fearing espionage) and reconstructed to serve the purposes of the warring states. Army photography and film units emerged under the supervision and censorship of staff headquarters. The Belgian Army Film Unit (Cinematografische dienst van het Belgisch leger / Service cinématographique de l'armée belge - henceforth: SCAB), established in I9I6, was part of this development. Stationed in the 'forward zone', the unit recorded visual material at the front between I9I6 and I9I8.

Until now, Belgian historians had never studied any visual material produced by the SCAB during the First World War, nor had they looked into the history of the Film Unit. However, in recent years moving pictures have become an invaluable source for historians, thereby giving a new breath of life to research on the First World War. ${ }^{2}$ It is crucial to consider not only the represented reality as depicted in the films, but also the cultural practices which surrounded the production and reception of such pictures. This article therefore aims to sketch a first approach to this Belgian Army Film Unit and to its filmic sources. The goal is to understand why the Belgian War Department gradually established an Army film unit and how it used its filmic production to write its own history at the Yser front. The article is based on the paper archives of the Belgian Propaganda Office, those belonging to the Belgian military headquarters $^{3}$ (the paper archives of the SCAB no longer exist), and on visual material from the SCAB.

In this respect, the first part of the article explores the context of the installation of the SCAB and its functioning. Did the First World War offer an opportunity to develop a state film practice in a country without previous history of newsreels production? The second part analyses the film productions of the SCAB on the basis of the remaining audio-visual sources 
in order to identify the vision of the conflict that they conveyed. The third and final part examines the reception of these images.

\section{The Great War, an opportunity to develop a state film practice?}

Both the cinematographic project of the Belgian military staff and government and the awareness of the potential of cinema during the First World War cannot be understood without referring to the notions of 'mass culture' and 'media culture' pre-dating the conflict and particularly to Belgium's small size. ${ }^{4}$ In the early twentieth century, 'cinema' still had to define its own identity. Close to both theatre and photography, cinema constituted a new form of 'show', a visual sort of performance that was actually not that different from other existing entertainment practices and technologies. Moreover, several types of media were often being mixed and combined in the same 'event'. Rick Altman argued that although the technological invention of cinematography dates from the end of the nineteenth century, its "social invention", or its "invention as a cultural practice", was still developing during these first decades. According to Altman, it was not until the second decade, after I9Io, that cinema acquired its own identity and became not only an amalgam of technologies but also a practice in its own right. ${ }^{5}$

A similar kind of identity construction was taking place in Belgium. Guido Convents' research shows the evolution in practice from the traveling theatres of the late nineteenth century to the Royal Decree of I3 July I908 that regulated by law the system of film rental and stipulated safety measures. ${ }^{6}$ The legislation encouraged the opening of permanent cinemas. ${ }^{7}$ Unlike the Netherlands, where investors and the public remained unenthusiastic vis-à-vis the new medium, cinema was quickly gaining ground in Belgium. On the eve of the war, cinema was a particularly popular leisure activity in Belgium and a distinct cultural practice. In I9I2 Amsterdam housed only 20 cinemas while Brussels already had $75 !^{8}$ More than 600 movie theatres opened in Belgium, making it one of the best-equipped European countries where cinema was concerned. By contrast, its national film production was underdeveloped, especially in terms of the newsreel production.

By becoming weekly features in 1908, newsreels regularly fit into the pre-war cinematographic practice. ${ }^{9}$ They were an integral part of the programmes leased by production companies and distributors. What is more, the job of newsreel operators started to enjoy recognition. However, this was not the case in Belgium, where no newsreels were being produced. Until the beginning of the conflict in I9I4, foreign newsreels (The French PATHÉ-

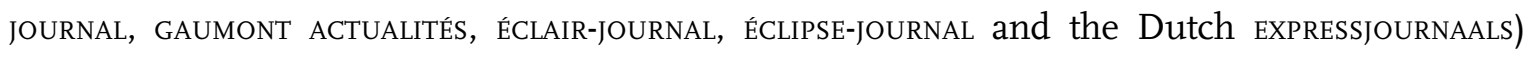
appealed to the Belgian audience. Yet, these foreign, standardized cultural products covered very few Belgian events. There were a few Belgian attempts such as MANĖGE ACTUALITÉs in Verviers or la SEMAine Animée (I9I2-I9I4) under the direction of Hippolyte de Kempeneer and Auguste Meuter, and newsreel subjects were filmed by Isidore Moray (founder of Laboratoire Cinématographique Belge - I9I2) for ÉClair-Journal. ${ }^{\text {IO }}$ However, Pathé and Gaumont companies had a monopoly on the market, countering any competition and preventing the development a Belgian newsreel practice. A few months before the war broke out, pictures of the Belgian Army were recorded by the French firm Pathé - instead of a Belgian film company 
(ReVue des troupes belges par S.M. Le Roi albert [i.e. the belgian military parade], Pathé - I9I4; la traction Canine dans l'armée belge. [i.e. the Canine traction in the belgian army], Pathé - I9i4).

On 4 August I9I4, Belgium saw the mass arrival of German troops on its soil. Even though cinemas were closed, newsreel correspondents recorded the 'sensational' event. This is why they filmed the first images of the military mobilization, but also pictures of the exodus of the civilian population following the advance of the enemy. In October I9I4, the Belgian government took refuge in Sainte-Adresse, near Le Havre (France). King Albert, however, wanted to remain close to his soldiers. ${ }^{\text {II }}$ On 9 November I9I4 he set up his headquarters in the last corner of unoccupied Belgium, behind the Yser front in De Panne, a small coastal town. During the first seven months of the conflict, the Belgian Army granted permission to foreign newsreels companies such as the French Gaumont and Pathé as well as the English Harry ${ }^{\mathrm{I2}}$ to shoot footage in training camps and behind the front lines, but never at the front itself. ${ }^{\mathrm{I}}$ In fact, on both sides newsreels companies were quickly forbidden to document what was happening on the first lines. ${ }^{\text {I4 }}$

At the beginning of the war the image of 'Poor Little Belgium' was an effective symbol that was largely fuelled by Allied propaganda and one-off Belgian initiatives. ${ }^{15}$ In the United States, for example, the propaganda department of the Commission for Relief in Belgium (a charity in charge of supplying food to German-occupied Belgium, established in November I9I4 and chaired by Herbert Hoover) spread a vision of Belgium as a victim of the war, a country in ruins populated by starving women and children. As a consequence, when the Army was mentioned in Allied propaganda, the soldiers looked pitiful and exhausted. Because it was growing increasingly worried about this feeble image, the Belgian government decided in I9I6 to change course and to coordinate its propaganda efforts (via the establishment of a Comité gouvernemental de propaganda [i.e. Governmental Propaganda Committee] and an Office de propaganda belge [i.e. Belgian Propaganda Office] ${ }^{\mathrm{T}}$ ) in order to propagate a favourable portrayal of Belgium as a tenacious, belligerent nation and worthy ally. ${ }^{17}$ Belgian propaganda was aimed at using all the communication media available at the time, including photography ${ }^{\mathrm{I}}$ and film. The belief in the capacity of this visual medium to influence public opinion was strong in the Belgian Propaganda Office: "Cinema produces the most lively and most durable impression on the public". ${ }^{\text {I9 }}$

Following the example of a similar development in France (the Section cinématographique des armées [i.e. Cinematographic section of armies] was created in February I9I5), ${ }^{20}$ at the end of I9I6 the Belgian War Department created the Service cinématographique del'armée belge, the Belgian Army Film Unit. ${ }^{2 \mathrm{I}}$ The SCAB was based in De Panne and had limited resources at its disposal. ${ }^{22}$ The Service was headed by lieutenant Horlait and included approximately five cameramen in addition to two staff members in the laboratory behind the front line. Only two of them are known to have some experience with film before the war: Isidore Moray ${ }^{23}$ had been a cinema owner and filmmaker in Brussels and Léon-Josse Dassonville had worked for KodakPathéFrance Company in Paris. It has been impossible to assert whether the other members of the SCAB were film professionals like the operators of the French Army film unit were. ${ }^{24}$

The SCAB's task was to shoot images of the Belgian Army in action and of its soldiers under the leadership of their commander-in-chief, King Albert and his wife Queen Elisabeth. 


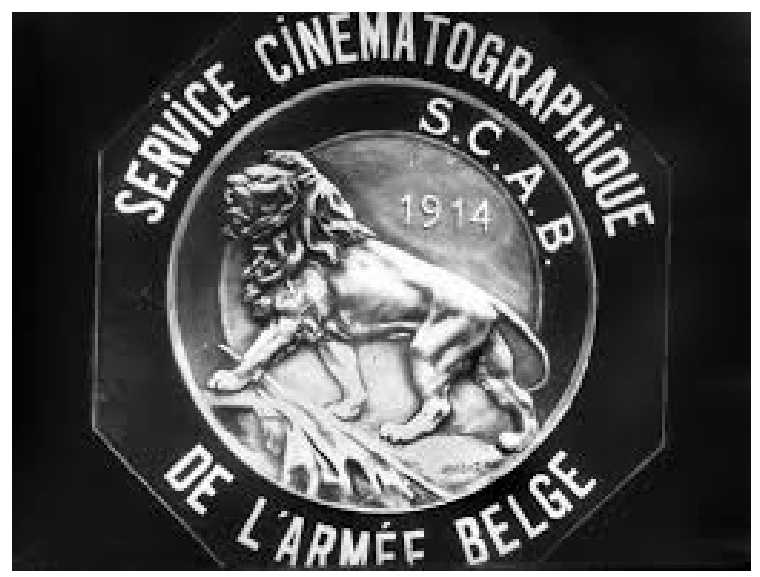

Opening title card of the SCAB, 1917. Cinematek, Brussels

As Henri Carton de Wiart, chairman of the Governmental Propaganda Committee, put it: “The moment has come to further highlight the heroic resistance and admirable energy of the Belgian nation and, in particular, our soldiers' bravery and their sense of initiative, and their remarkable efforts undertaken under your leadership in order to make our rebuilt Army as strong as it can be". ${ }^{25}$

We know very little about the first months of the SCAB's existence, except that it played the key role in the development of a state cinematographic practice for the first time in Belgium, in the form of a rigorously controlled military film production. All shots were scrutinized by the sharp-eyed censors of the military headquarters: they ensured that "benchmarks of our front that the enemy could identify" would not be shown. ${ }^{26}$ In case of footage of the royal family, the shots had to be censored by the King's Secretary or the King himself: rejected shots were simply destroyed. ${ }^{27}$ Despite harsh censorship, the SCAB recorded visual material of the Yser front from the end of I9I6 to I9I8, including some aerial shots that are priceless from our present perspective. The films were edited with the assistance of the laboratories belonging to French company Éclair.

Unlike what happened in other countries involved in the conflict, the Belgian film propaganda could not be shown to Belgian civilians because of the German occupation. The SCAB productions were shown to the Belgian soldiers, but also in Allied and neutral countries. Relying once again on the experience of its French ally, which had been screening newsreels since January I9I7 (ANNALES DE LA GUERRE), the Belgian War Department decided to produce a weekly newsreel series, ySER JOURNAL [i.e. YSER NEWs] as of October I9I8. One month later, the war was over, which meant that civilians in all Belgian cinemas then had access to viewing it.

\section{SCAB films at the Yser front}

According to a document found in the archives of the Belgian Propaganda Office, between I9I7 and the end of the war (November I9I8) the Belgian film unit recorded I2,400 meters of film stock, divided over I,637 shots of lengths varying between I and 20 meters, lasting not more than one minute each. How many of these shots were edited? Which ones were screened? These questions will always remain unanswered because the largest part of this visual material on World War I has disappeared since then. The present audio-visual service of the Belgian Ministry of Defence, installed on the military base of Peutie ${ }^{28}$ has kept visual material from the 
SCAB since its inception; however, during the May I940 bombings, most of the film prints and negatives were destroyed. These probably included the 1,637 shots of the Great War. Some films were nevertheless saved and some copies were recovered in 1950 after a survey by the aforementioned audio-visual service.

Some SCAB productions (in particular these kept by the Belgian Film Archives, also known as the 'Cinematek') have been rediscovered recently, complementing the collection of Peutie. The centenary of the Great War spurred interest for audio-visual archives from the period: "The national archives of the countries involved in the conflict have been overwhelmed the past couple of years with requests coming from film production companies and broadcasting companies to the point that there is at times little room left for the academic research which is also stimulated by the prospect of the Great War centenary". ${ }^{29}$ At the same time, this surge of interest also contributed to digitization campaigns of visual archives, ${ }^{30}$ which provides researchers access to very useful databases, such as the European Film Gateway project devoted to archival images about the First World War, ${ }^{3 \mathrm{I}}$ or DVD compilations such as the one made by the Belgian Film Archives. ${ }^{32}$

Nowadays, most of the SCAB productions available at the audio-visual service of the Belgian Ministry of Defense and at the Belgian Film Archives are post-war productions (I9I8I922), among which some yser journal newsreels and many post-war anniversary films and compilations put together by the SCAB. However, all of them used original footage shot by the SCAB at the Yser front during the conflict. They are now often considered as the only remaining window on the original footage of the Great War, which has probably disappeared forever. These filmic sources are too limited to make detailed analyses, although it is possible to sketch some tendencies. Besides, this military audio-visual heritage offers outstanding sources to study Belgian national propaganda as well as the issue of memory of the First World War in Belgium during the interwar period. The SCAB films appear to be quite similar to the French newsreels as analysed by Laurent Véray, both in terms of content and themes, as well as filming techniques, such as the positions of the operator. ${ }^{33}$

We know virtually nothing about the authors of the SCAB's visual documents. In this period, filmmakers (of both newsreels and fiction films) usually remained anonymous; film credits did not feature any names, except that of the 'official author' - in this case, the SCAB (and behind it, the Belgian War Department). All these films included an opening title card that was typical of the SCAB, depicting the Lion that protects with its powerful claws the Belgian flag that has fallen into the dirt. Besides, we know that the available equipment from the early $20^{\text {th }}$ century had a major influence on the shooting. The operator was hampered by 40 kilograms worth of camera, tripod and film. Needless to say, operators could not remain unnoticed. All the shots were probably made with the 'consent' of the filmed people or at least their awareness. The tripod did not allow the operator to follow the soldiers in the heat of the action (unlike what a cameraman could do during the Second World War with a portable camera on the shoulder). Furthermore, the amount of footage these cameras could contain was limited. As a result, the shots were short sequences where the operators had "a greater freedom of action, enabling them to organize and stage the shots", ${ }^{34}$ which is a typical characteristic of fiction. Most of the shots were re-enactments in which the soldiers performed their own roles. 
These images suggested the fights but did not actually show them: no bayonet charges, no hand-to-hand fighting or shelling of the trenches were ever presented to the public. Under the heading 'scenes from the front', the films featured a long left to right panning shot of a deserted no-man's land; none of the violence of the battles was actually shown. Another element that could account for this lack of filmed fighting material is that the Yser front was rather quiet. After the German invasion was stopped following the Battle of the Yser in October I9I4, the frontline did not move substantially. A large flooded area around the River Yser kept the German Army at a 'safe' distance. Until the Belgian Army started moving forward in the spring of I9I8, the Yser Front was not very spectacular.

It is also because of the technical obstacles that one subject prevailed in the images filmed by the SCAB, just like in French newsreels, namely the "daily life at war: haunting photography on the outskirts of combat" ${ }^{\prime 3}$ : daily life in the trenches (transport of materials, heavy weapons); technical progress; battle preparations (soldiers cleaning guns, working on the equipment); fortification works on the rear trenches; food and artillery supply; care and transport of wounded... According to film historian Pierre Sorlin, "the soldiers seemed locked in routine". ${ }^{6}$

To counter the lack of footage of the fights and violence, various tricks were used by the filmmakers in order to suggest military action in the SCAB films. The fights were almost systematically represented by animated maps showing the advances and retreats of the armies. ${ }^{37}$ The inclusion of drawings and photographs made it possible to evoke the first months of the war, when the cameras were not allowed at the front. The title cards and the editing would suffice to tell the story. There were proportionately more title cards than live images, which were simply lacking. Both intertitles and moving images were evidence of the authenticity of the events and they reinforced the accusations directed at the German aggressor. For example, after images of the ruins of Ypres, the final title card of the newsreel YPRES 2 stated: "These ruins point the finger at the ones who are to blame. They are screaming out: 'You are the criminals!" ${ }^{8}$ Because it was impossible to show violence, the SCAB suggested it by including emotional images in its films such as shots of the ruins and of the injured. As a result, ruins monopolize screen time, with long horizontal and vertical panning shots of piles of bricks in towns and cities, of destroyed roads, buildings, churches, etc. 'Before' and 'after' shots demonstrate the extent of the devastation. Among the dramatic images that were meant to affect the viewers most were sequences devoted to the injured and the crippled, reminding everyone of a husband, a son or a father who had been at the front. ${ }^{39}$ These images of permanently disabled men were intended to bear witness not only to German savagery, but also to the sacrifices made by Belgian soldiers.

King Albert of Belgium played a leading role in these films of the SCAB. The King dominated the screen: Albert always looked solemn and seemed not to pay attention to the camera. The King impressed the audience with his military uniform and his height: Albert's stature surpassed that of all the international leaders. ${ }^{40}$ He quickly became the idol of SCAB's operators. Another royal face was constantly associated with the wounded: that of Queen Elisabeth of Belgium. While her name was sometimes simply written in the centre of the title card, on other occasions she appeared on the screen, becoming the focus of the camera operators as they captured her every deed and gesture. The Queen was depicted as a heroine 
visiting injured soldiers. These shots of Queen Elisabeth strengthened the myth of the 'Nursing Queen' propagated by the Royal Household during the war. ${ }^{4 \mathrm{I}}$ In fact, the camera had been a real propaganda tool for King Albert since he had ascended the throne in I909; the cinema further enhanced his popularity. Albert and Elisabeth would go on to use this medium to build their carefully controlled image, that of a glamorous couple. The camera would become a tool of communication at national and international levels as well as a means of asserting political strategies before, during, and after the war. ${ }^{42}$ The monarch personified the national tradition. His image proved to be very useful in international propaganda. Indeed, the propaganda of I9I4-I9I8, and in particular that of the SCAB, largely relied on it.

\section{The reception of the SCAB films}

In I9I7 and I9I8, during the war, SCAB productions could not be screened in the occupied Belgian cinemas and were only shown to the Belgian soldiers and to cinema audiences in Allied and neutral countries, as mentioned above. The newsreels were distributed internationally through the Belgian Propaganda Office and its foreign agencies in England, Switzerland, the United States and the Netherlands. However, the impact of this Belgian film propaganda seems very limited, especially in the United States. For Belgian propagandists abroad, these films were often inadequate, unremarkable, and did not compare at all to American productions. ${ }^{43}$ In a letter to the Propaganda Office in I9I7, Émile Cartier de Marchienne, a Belgian diplomat established in Washington, complained about the films that were sent to him: "They sent me among other things a film representing the construction of a well in La Panne. Our brave soldiers worked so slowly that it made the audience laugh. Another film was titled 'Alerte' [Alarm], but even for me, not a military man, it was clear that this was a fake alarm. The Americans are spoiled by films from the French and British Armies, taken in the midst of the action. Compared to them, we leave a poor impression, and that is one among a thousand little reasons why the idea that the Belgian Army hardly does anything is so widespread". 44

Further study of the reception of Belgian newsreels in the Netherlands would be worthwhile because preliminary evidence has shown that the Belgian films seemed to have been welcomed slightly more positively than in the United States. The relative success of the occasional screenings could be explained by the fact that they were mainly aimed at Belgian refugees ${ }^{45}$ and detained Belgian soldiers, delighted to get any news from home at all. Films from the SCAB gave them the opportunity to see King Albert and (unfortunately disastrous) pictures of their ruined cities. Cinema owners seemed keen on screening the films not because of their quality or the potential profit, but mainly because they could be used to create a balance with the German, British and French official propaganda films that were already available. Balancing the programmes was a crucial issue in the neutral Netherlands. Karel Dibbets and Wouter Groot discussed the influence of propaganda films screened in the Netherlands. Since this film propaganda could compromise the neutrality of the country, it affected not only the distributors and cinema owners, but also intelligence services and politicians. The distribution channels of French firms, which had already developed in the Netherlands before the war, facilitated the distribution of productions from the French Army Film Unit. ${ }^{6}$ One could 
speculate that this network could have been used to distribute SCAB films, but this question does not fall within the scope of the present paper; it does, however, deserve further research.

\section{Concluding remarks: a state film practice nipped in the bud}

In I9I9 the SCAB moved to offices located at Place de la Justice in Brussels with Major Fernand Poureau as head, while its cinematic laboratory continued to be run by Isidore Moray. Yser Journal continued, but had to adapt to face competition from foreign newsreels on the Belgian market. In addition to the French newsreels, American giants such as UNIVERSAL NEwS (from I9I2), MGM NEWS OF THE DAYs (from I9I4), FOX NEWs (I9I9), etc., filled the Belgian screens. ${ }^{47}$ In 1920 the SCAB decided to give a new title to its newsreels: LA SEMAINE BELGE [The Belgian week]; political, artistic and sports sections were added to the military subjects. The SCAB could not, however, compete with the performance and the financial power of American companies: the production of LA SEMAINE Belge STOPPED in I92I. The media landscape witnessed the birth of a new instrument in the post-war years: the radio, a popular tool that could reach the masses in their own homes, would also become a weapon for the propagandists. The Belgian state abandoned the newsreels and invested in the public radio instead. ${ }^{48}$

However, the state cinematographic practice that appeared during the war did not vanish completely. The SCAB abandoned its production of newsreels, but it kept informing the population about the efforts that the Army had undertaken during the past four years of war. At the end of the war, Belgium was greatly weakened. It had to be rebuilt in a difficult environment, combining both internal tensions (political and social inequalities; judicial repression against people who had collaborated with the German occupiers, ${ }^{49}$ etc.) and international ones. Several governments of national unity tried to implement major constitutional and social reforms. ${ }^{50}$ Nevertheless, it was also a time to celebrate victory, to commemorate and to remember. Military parades, patriotic ceremonies, memorials, etc. throughout the country were accompanied by a profusion of Belgian films about the war and people's memories of it during the interwar period: "As soon as the war ended, cinema became the main medium on which Belgium, like the other nations involved in the conflict, relied for their appropriation of the memory of the 'great catastrophe'". ${ }^{\mathrm{I}}$ However, the memory of the Great War and patriotic fervour were gradually decreasing. As Rosoux and van Ypersele argued, "the nation had never before seemed so united in feeling, nor had the Belgian national identity ever before seemed so strong. However, as early as the I920s, it became apparent that this outburst of national fervour would not last". ${ }^{2}$

In fact, the 'Belgian feeling' deteriorated during the conflict. In the post-war years, the Flemish-nationalist movements blossomed. The Northern and Southern parts of the country each took divergent paths and adopted distinct ideological causes. This fracture was also reflected in documentaries because the SCAB records ${ }^{53}$ were recycled by different ideological groups, each with a particular 'war culture'. These documentaries exploited the SCAB footage to serve their own purposes. On the one hand, the SCAB, which had a large supply of visual material of the front at its disposal, used this material when it considered it fit and edited documentaries that combined archive footage and re-enactments. By doing so the SCAB put forward its own view of the Belgian Army by placing the courageous, valiant soldier in the 
spotlight, as depicted in the most evocative of these documentaries, $\AA$ LA GLOIRE DU TROUPIER Belge (i.e. to the Glory of the Belgian pRivate, I922). The SCAB productions conveyed the image of a united nation personified by the so-called 'Knight King'. On the other hand, official footage made by the Belgian Army to document its heroism and greatness was also used to spread a diametrically opposed message when used by Flemish-nationalist movement. These SCAB records became a vehicle for a pacifist and Flemish-nationalist discourse, as seen in the film MET ONZE JONGENS AAN DEN IJZER - AVEC NOS GARS SUR L'YSER (i.e. WITH OUR TROUPS ON THE YSER, I928) by Flemish-nationalist filmmaker Clemens De Landtsheer. ${ }^{54}$

These interwar film productions would leave contrasting and long-lasting imprints on the logic of memory in the northern and southern parts of the country: they "have contributed to the production and the perpetuation of a fractured national narrative". ${ }^{55}$ Historian Louise Stokart has demonstrated that this fractured national narrative was reflected in the television broadcasts for the fiftieth anniversary of the Great War. ${ }^{56}$ Nowadays, on the occasion of the centenary celebrations, one question remains: "In what way is the approach of Belgian cinema towards national narratives still imbued with old patterns [i.e. dating back to the interwar period] nowadays? New screenplays, old myths?"57 After the 2018 commemorations, it might be worth analysing contemporary films and documentaries in order to identify how the SCAB film archives have been used in Belgian cinema and what kind of narrative of the Great War they suggest.

\section{Notes}

I. J. Beurier, 'La Grande Guerre, matrice des médias modernes', in: Le Temps des Médias, 2005/I, n4, p. I62-I75.

2. Notably for First World War pictures. See for example for France, L. Véray, Les films d'actualité français de la Grande Guerre, Paris, I995; L. Véray, La Grande Guerre au cinéma, de la gloire à la mémoire, Paris, 2008 ; V. Challéat, 'Le Service cinéma des armées', in: 1895 : revue d’histoire du cinéma, juin 2008, n55, p. I74-I80; C. Puget, 'Les preuves de Verdun. Documentaire(s) et fiction(s) en bataille', in: J.-P. Bertin-Maghit (ed.), Lorsque Clio s'empare du documentaire, Vol. I, 20II, p. I27-I38. For Great-Britain, see works of L. McKernan (ed.), Yesterday's news. The British Cinema Newsreel Reader, London, 2002, N. Reeves, The power of film propaganda: myth or reality, London, I999. For Germany, please refer to book by U. Oppelt, Film und Propaganda im Ersten Weltkrieg: Propaganda als Medienrealität im Aktualitäten- und Dokumentarfilm, Stuttgart, 2002.

3. Royal Museum of the Armed forces and of Military History (RMA), ex A32/225, files I-4, First World War.

4. The term 'mass culture' refers "to an audience, real or assumed, with all the ambiguities associated with this hypothetical reception". The term 'media culture' should be understood as a "culture connected to the support: productions, uses and effects of the media”. M. Lits, 'La culture médiatique, ou la contamination de la culture par les médias', in: J.-Y. Mollier, J.-F. Sirinelli, F. Valloton (ed.), Culture de masse et culture médiatique en Europe et dans les Amériques, 1860-1940, Paris, 2006, p. 5 I.

5. R. Altman, 'Penser l'histoire du cinéma autrement : un modèle de crise', in: Vingtième Siècle. Revue d'histoire, $\mathrm{n}^{\circ} 46$, April-June I995, p. 67.

6. On early cinema in Belgium, see G. Convents, Van Kinetoscoop tot Cafe-Cine de Eerste Jaren van de Film in België, 1894-1908, Louvain, 2000.

7. G. Convents, 'Les catholiques et le cinéma en Belgique', in: R. Cosandey, A. Gaudreault (ed.), Une invention du diable? Cinéma des premiers temps et religion, Laval, I992, p. 27.

8. To understand these different film cultures and practices between Belgium and the Netherlands, see G. Convents, K. Dibbets, 'VerschiedeneWelten Kinokultur in Brüssel und in Amsterdam I905-I930', in: C. Müller, H. Segeberg (ed.), Kinoöffentlichkeit 1895-1920: Entstehung, Etablierung, Differenzierung, Marburg, 2008, p. I48-I54. 9. In 1907 Albert Galveau invented the first periodical newsreels for Frenchman Charles Pathé: Le Pathé-journal. Le Pathé-journal became a weekly programme in igo8. Until then, newsreels were projected on an irregular basis. 
See M. Aubert, 'La naissance de la presse filmée en France I895-I914', in: C. Jeavons, D. Kirchner (ed.), The Story of the century! An International Newsfilm conference, London, I998, p. I2.

Io. G. Convents, 'Van gefilmde actualiteiten tot bioscoopjournaal in België. De ontwikkeling van het nieuws op het witte doek (I896-I9I8)', in: Belgisch Tijsdschrift voor Nieuwste Geschiedenis, XXXIX, 2009, p. 40-43.

II. L. van Ypersele, Le roi Albert, histoire d'un mythe, Bruxelles, 2006.

I2. According L. Véray, during the first seven months of the conflict, the proportion of Belgian (or English) images was prominent in the Gaumont and Pathé newsreels. L. Véray, 'Montrer la guerre: la photographie et le cinématographe', in: A. Becker et al. (ed.), Guerre et cultures 1914-1918, Paris, I994, p. 234.

13. RMA, ex A32/225, file I, Letter from Broqueville to Carton de Wiart, 29 August i9i6.

I4. This military position already existed during the Anglo-Boer War (1899-1902) - operators filmed military operations, however, as Pierre Sorlin argues, "only a few cameramen went to the Transvaal. They were seldom allowed to visit the zone of operations and had to work in the rear. And some films were obvious 'fakes' since the pictures were perfectly sharp, the soldiers efficient and everything was under control”. P. Sorlin, 'Film and the War', in: J. Horne (ed.), A companion to World War I, Oxford, 20I2, p. 353.

I5. M. Amara, 'La propagande belge et l'image de la Belgique aux États-Unis durant la Première Guerre mondiale', in: Belgisch Tijsdschrift voor Nieuwste Geschiedenis, XXIX, nI-2, 2000, p. 173-226.

I6. On the establishment of propaganda offices, see M. Amara, 'Les grands défis de la propagande belge durant la Première Guerre mondiale', in: B. Rochet, A. Tixhon (ed.), La petite Belgique dans la Grande Guerre. Une icône, des images, Namur, 2012, p. 2I-35.

I7. RMA, ex A32/225, file I, Decision of the Belgian government, Le Havre, 20 June I9i6.

I8. On 5 November I9I5 the Ministry of War created the 'Service photographique de l'armée belge' (SPA, the Photographic Unit of the Belgian Army), which was based in Bourbourg (France). The SPA joined forces with the SCAB in I9i6.

I9. RMA, ex A32/225, file 4, Belgian Propaganda Office to Ministry of War, April I9I8.

20. See L. Véray, Les films d'actualité français de la Grande Guerre, Paris, I995.

2I. RMA, ex A32/225, file I, Letter from Broqueville to Carton de Wiart, 29 August I9I6.

22. On the genesis and archives of SCAB, see B. Rochet, 'Plongée au cœur des prises de vues du service cinématographique de l'armée belge : un matériel visuel de la Grande Guerre à multiples usages', in: B. Rochet, A. Tixhon (ed.), La petite Belgique dans la Grande Guerre. Une icône, des images, Namur, 20I2, p. III-I28.

23. On Isidore Moray, see M. Thys, Le cinéma belge, Brussels, I999, p. 50.

24. The different operators of the French Army film unit worked for the four French newsreels companies: Pathé, Gaumont, Éclair and Éclipse.

25. RMA, ex A32/225, file I, Letter from Carton de Wiart to de Broqueville, 20 June I9I6.

26. RMA, ex A32/225, file I, Letter from Broqueville to Beyens, 23 July i9ı6.

27. DG-IPR Archives, Ministry of Defense, Peutie. Commandant Poureau, Souvenirs de mon activité au SCAB, I940.

28. DG-IPR Archives, Quartier Major Housiau, Ministry of Defense, Peutie (Belgique).

29. J. Hamers, G. Van Cauwenberge, 'From propaganda to commemoration: reworking the national narrative', in: Rethinking History: The Journal of Theory and Practice, I8:3, 20I4, p. 435.

30. Some of the films made by the SCAB are also part of the Royal Belgian Film Archive. The reels of the Ministry of Defense, including original nitrate films, are now in the process of being transferred to the vaults of the Royal Belgian Film Archive that will take care of its conservation and documentation. Some of them can be consulted online through the European Film Gateway - EFG I9I4-I9I8.

3I. http://www.europeanfilmgateway.eu/ On newsreels history, see also http://bufvc.ac.uk/newsonscreen/

32. L. Engelen, E. Martens, B. Rochet, A. Van Cutsem, The Great War in Belgian Cinema, DVD, Cinematek, Brussels, 20I4.

33. L. Véray, Les films d'actualité français de la Grande Guerre, Paris, I995.

34. L. Véray, La Grande Guerre au cinéma, de la gloire à la mémoire, Paris, 2008, p. 23.

35. L. Gervereau, Montrer la guerre? Information ou propagande, Paris, 2006.

36. P. Sorlin, 'Film and the War', p. 355.

37. DG-IPR Archives, Ministry of Defense, Peutie. Newsreels of the SCAB, for example, 'Les anniversaires tragiques et glorieux', a series (edited in I9I9) of commemoration films of battles dating from the German advance and the race to the sea in I9I4.

38. DG-IPR Archives, Ministry of Defense, Peutie. Final title card of the "Ypres 2" newsreels, probably dating from I920. 
39. DG-IPR Archives, Ministry of Defense, Peutie. Newsreels of the SCAB "Nos hôpitaux" (Our hospitals), "Nos aveugles de guerre" (Those blinded in the war), "La rééducation de nos grands blessés" (Rehabilitation of our great wounded), I9I8-I9I9.

40. DG-IPR Archives, Ministry of Defense, Peutie. Newsreels of the SCAB "S.M. le roi Albert décore des soldats de la Première division d'armée", I9I7; "Visite en Belgique de M. Poincaré, Président de la République Française”, I9I9.

4I. DG-IPR Archives, Ministry of Defense, Peutie. Newsreels of the SCAB "Nos hôpitaux" (Our hospitals), "Nos aveugles de guerre" (Those blinded in the war), "La rééducation de nos grands blessés" (Rehabilitation of our great wounded), i918-igi9.

42. Ch. Kesteloot (ed.), Albert Q Elisabeth. De film van een koninklijk leven. (Met een voorwoord van koning Filip), Brussel: Hannibal, 20I4.

43. M. Amara, 'La propagande belge et l'image de la Belgique aux États-Unis durant la Première Guerre mondiale, in: Belgisch Tijsdschrift voor Nieuwste Geschiedenis, XXIX, n I-2, 2000, p. 173-226.

44. AEB (Ministry of Foreign Affairs, Brussels), P 88, Df. ı०o, Cartier de Marchienne to Mélot, 6 October I9I7.

45. See M. Amara, Des Belges à l'épreuve de l'Exil. Les réfugiés de la Première Guerre mondiale (France, Angleterre, PaysBas), Brussels, 2008.

46. K. Dibbets, W. Groot, 'Welke Slag aan de Somme? Oorlog en neutraliteit in Nederlandse bioscopen, I9I4-I9I8', in: Tijdschrift voor Geschiedenis, r22e jaargang, $\mathrm{n}^{\circ} 4$, p. 5 12.

47. On the interwar newsreels in Belgium. see D. Biltereyst, R. Vande Winkel, 'Filmjournaals in België (I9I8I994', in: BTNG/RBHC, Brussels, XXXIX, 2009, p. 53-92.

48. Radio-Bruxelles, which became Radio-Belgique (I924) and INR - Institut National de Radiodiffusion (I930), was inaugurated in November I923.

49. Between I9I9 and I922, those who collaborated with the occupiers (the Flemish activists) and the profiteers that benefited from the war are targeted by a strict legal crackdown. See X. Rousseaux, L. Van Ypersele, 'La répression de l'incivisme en Belgique au travers de la presse francophone bruxelloise et des procès de la cour d'assises de Brabant (I918-1922)', in: L. Van Ypersele (ed.), Imaginaires de guerre: l'histoire entre mythe et réalité, Louvain-La-Neuve, 2003, p. 253-302.

50. One of them is the introduction of simple universal suffrage for all men over 2I, "a reform imposed by Albert and his advisers without consulting the (former) Le Havre government, and pushed through without a constitutional revision approved by parliament. (...) Universal suffrage for men, an urgent issue even before the war, was an absolute priority in a post-war cultural context that exalted soldiers' sacrifice”. S. De Schaepdrijver, 'Belgium', in: J. Horne (ed.), A companion..., p. 396.

5I. J. Hamers, G. Van Cauwenberge, From propaganda, p. 425.

52. V. Rosoux, L. Van Ypersele. 'Le passé national belge: entre commémoration et silence', in: O. Luminet (ed.), Belgique-België: Un état des lieux, deux mémoires collectives, Wavre, 2012, p. 59.

53. The SCAB had no concern for the commercial value of its films. It sold for a very low price all footage of the conflict at the rate of one Belgian franc for one meter of footage. RMA, ex A32/225, file 3, Belgian Propaganda Office to Marsily, 23 January I9I9.

54. On this subject, see D. Biltereyst, R. Vande Winkel, Filmen voor Vlaanderen.Vlaamse beweging, propaganda en film, Antwerp, 2008.

55. J. Hamers, G. Van Cauwenberge, From propaganda..., p. 423.

56. L. Stokart, Le Cinquantenaire de la Grande Guerre vu par la RTB. Les émissions «14-18. Le journal de la Grande Guerre », unpublished MA thesis, UCL, 20I4.

57. J. Hamers, G. Van Cauwenberge, From propaganda..., p. 431. 